\title{
アップコンバート画像の超解像処理に向けた拡大前の画素数およ びリサンプリング位相の推定法
}

Estimate of the Original Number of Pixels before Enlarging and Re-sampling Phase for Superresolution from an Up-converted Image

\author{
正会員 影山昌広 ${ }^{\dagger}$, 正会員 浜田宏一 ${ }^{\dagger}$
}

Masahiro Kageyama $^{\dagger}$ and Koichi Hamada ${ }^{\dagger}$

あらまし 超解像处理が「折返し成分として画像に現れている高周波成分を正しく復元する処理」であることを鑑み ると，すでに拡大されたアップコンバート画像を超解像処理する際に，撮像からアップコンバート画像に至る過程に 扔ける折返し成分の挙動を正確にモデル化することが重要である。しかしながら，未知の倍率で拡大されたアップコ ンバート画像の場合には，折返し成分の挙動を正確にモデル化することが困難であった？そこで本稿では，このモデ ル化に必要な「拡大前の画素数, および折返し成分の位相を決定づけるリサンプリング位相」の推定手法を提案する. 画像拡大前のナイキスト周波数では, ベースバンド成分と折返し成分の信号強度が必ず一致し，複素平面上で信号が 直線状に分布することを利用して, 未知の倍率で拡大されたアップコンバート画像に扔ける拡大前の画素数およびリ サンプリング位相を推定する．シミュレーション実験によって提案手法の有効性を示した.

キーワード: アップコンバート画像, 超解像処理, 画素数, リサンプリング位相, 折返し, 複素平面

\section{1.まえがき}

撮像時の解像度限界 (ナイキスト周波数) を超えて，画像 に含まれる高周波成分を復元し高解像化する超解像処理の 技術開発が盛んである ${ }^{1)}$. 超解像処理として, 複数の画像 を1枚に合成して高解像化する処理が広く用いられている. この処理は，周波数領域の折返し成分（エイリアシング）と して画像に現れている高周波成分を正しく復元する処理で ある1).

超解像処理は, 画像の拡大を伴うことが多く, 所望の拡 大倍率を明示的に処理パラメータとして設定するのが一般 的である。その一方で, 未知の倍率で拡大された画像を入 力として, 超解像処理したい場合もある. 本稿では, この ような「すでに拡大されている画像」のことを, アップコン バート画像と呼ぶことにする。

超解像処理には, 逐次近似による逆変換手法 $\left.{ }^{2)} \sim 4\right)$ や, 入 力信号をフーリエ変換して周波数領域で連立方程式を解く 手法 ${ }^{5)}$, 位相シフトを利用した手法 ${ }^{6)}$ 7) などが利用されてい る.これらのいずれの手法においても, 超解像処理が「折 返し成分として画像に現れている高周波成分を正しく復元 する処理」1)であることを鑑みると，撮像からアップコン

2014年3月 31 日受付, 2014 年 7 月 29 日採録

†株式会社日立製作所中央研究所

（テ185-8601 東京都国分寺市東恋ヶ寉1-280，TEL 042-323-1111）
バート画像に至る過程における折返し成分の挙動を正確に モデル化することが重要である.

仮に，拡大処理の詳細が既知であれば，折返し成分の挙 動をモデル化することは比較的容易である。その一方で, 未知の倍率で拡大されたアップコンバート画像の場合に は，折返し成分の挙動を正確にモデル化することはこれま で困難であった。

そこで本稿では，このモデル化に必要な「アップコン バート画像における拡大前の画素数とリサンプリング位相 (後述)」の推定手法を提案する. 2 章で拡大前の画素数・位 相を推定することの重要性について述べたのちに，3章で 提案手法について述べ，4章でシミュレーション実験に よって提案手法の有効性を示す.

\section{2. 拡大前の画素数・位相を推定することの重 要性}

本章では，一般的なアップコンバート処理について説明 したのちに, 超解像処理の代表例を挙げて, 拡大前の画像 の画素数とリサンプリング位相 (後述)を推定することの重 要性を説明する.

まず，図1を用いてアップコンバート処理について説明 する。同図 (a) は, 同処理の構成を示したものであり， $\mathrm{m} / \mathrm{n}$ 倍 (ただし， m, n は正整数) に拡大する際には， $\mathrm{m}$ 倍 アップサンプリング (零挿入)を行ったのちに, LPF (Low 


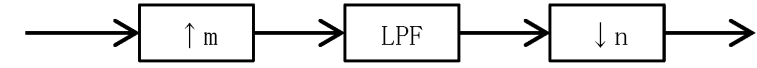

$\uparrow \mathrm{m}: \mathrm{m}$ 倍アップサンプリング(零挿入) $\downarrow \mathrm{n}: 1 / \mathrm{n}$ ダウンサンプリング(間引き) LPF : Low Pass Filter （ただし、m，nは正整数）

(a) 構成
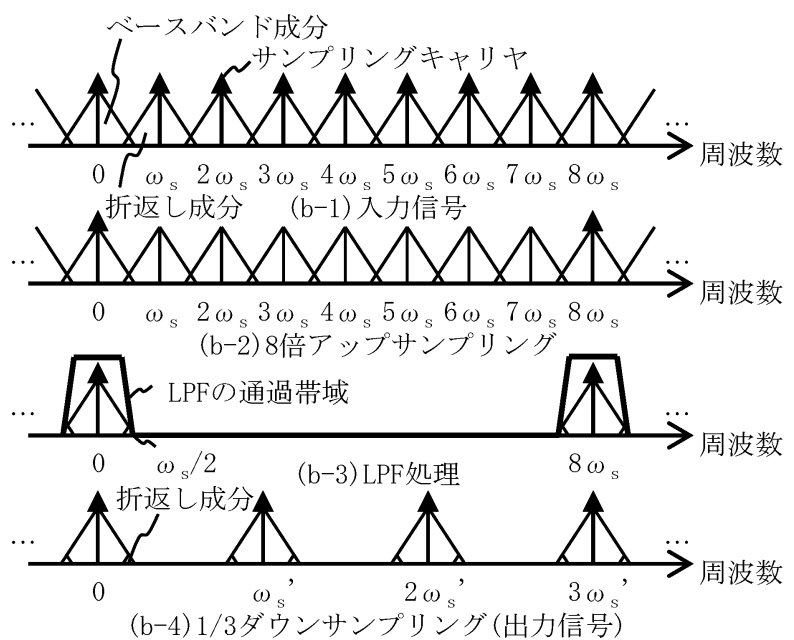

(b) 周波数スペクトル (例 : $8 / 3$ 倍拡大 $(m=8, n=3))$

図1 アップコンバート処理

Pass Filter)によって不要な折返し成分を除去し， $1 / \mathrm{n}$ ダウ ンサンプリングを行う。

図 1 (b) は，8/3 倍拡大 (すなわち $\mathrm{m}=8, \mathrm{n}=3$ )を例に挙げ て各段階の周波数スペクトルを示したものである. 同図 （b-1）に示す入力信号は, ベースバンド成分と, サンプリ ングキャリヤ(周波数 $\omega_{\mathrm{s}}, 2 \omega_{\mathrm{s}}, 3 \omega_{\mathrm{s}} \cdots$ ) によってベース バンド成分が畳み込まれた折返し成分からなる。

ここで, 超解像処理の効果を得るためには, ベースバン ド成分の最高周波数がナイキスト周波数 $\left(\omega_{\mathrm{s}} / 2\right)$ を超え, 折返し成分との重なりが生じている必要がある ${ }^{1)}$.

図 1 (b-2) は，8倍アップサンプリング後の周波数スペク トルを示して抢り, サンプリングキャリヤの周波数の間隔 が $\omega_{\mathrm{s}}$ から $8 \omega_{\mathrm{s}}$ に広がることを示している.

図 1 (b-3) は, LPF 処理後の周波数スペクトルを示してい る. $\mathrm{LPF}$ 処理により, $\omega=0$ と $\omega=8 \omega_{\mathrm{s}}$ の近傍の周波数成 分だけを残し，その他の周波数成分は除去される。このと き, ナイキスト周波数 $\left(\omega_{\mathrm{s}} / 2\right)$ 以上の周波数成分は, 折返 し成分として残留する。

図 1 (b-4) は，1/3 ダウンサンプリング後の信号 (出力信 号) の周波数スペクトルを示しており, アップコンバート 後のサンプリング周波数 $\omega_{\mathrm{s}}{ }^{\prime}\left(=8 \omega_{\mathrm{s}} / 3\right)$ の整数倍の位置に 新たなサンプリングキャリヤが生じる，このキャリヤに よって, LPFを通過した成分が畳み达まれる。

アップコンバート画像に対する超解像処理では, 図 1 (b-4) に示した信号から，折返し成分として残っている高周波成 分を正しく復元する必要がある.

続いて, 超解像処理の動作原理を, 文献4)に記載されて いる手法を例に挙げて説明する。この手法では, 高解像画
像が低解像画像に劣化する過程 (変形，ほけ，縮小，ノイ ズ）を式（1）でモデル化し，逆演算を行うことによって，N 枚 (Nは正整数) の低解像画像から高解像画像を得る.

$$
\mathrm{Y}_{\mathrm{k}}=\mathrm{D}_{\mathrm{k}} * \mathrm{H}_{\mathrm{k}} * \mathrm{~F}_{\mathrm{k}} * \mathrm{X}+\mathrm{E}_{\mathrm{k}}(1 \leq k \leq N)
$$

なお, Xは高解像画像 (出力画像), $\mathrm{Y}_{\mathrm{k}}$ は再構成処理に用 いる N枚の低解像画像 (入力画像)の中の1枚を表す。また, $\mathrm{D}_{\mathrm{k}}$ は画像縮小, $\mathrm{H}_{\mathrm{k}}$ は点広がり関数 (PSF: Point Spread Function), $\mathrm{F}_{\mathrm{k}}$ は各低解像画像 $\mathrm{Y}_{\mathrm{k}}$ に対応した変形, *は睍 み込み演算をそれぞれ表し，これにノイズ $\mathrm{E}_{\mathrm{k}}$ を加算するこ とで, 高解像画像 $\mathrm{X}$ から低解像画像 $\mathrm{Y}_{\mathrm{k}}$ が得られる, と定 義する. 再構成処理では, この過程を逆演算することで, $\mathrm{N}$ 枚の低解像画像 $\mathrm{Y}_{\mathrm{k}}$ から高解像画像 $\mathrm{X}$ を得る。この逆演算 は，反復演算によって行うのが一般的である.

この中で， $\mathrm{H}_{\mathrm{k}}$ (PSF)の推定には，例えば文献8）9）のよ うな検討例がある。また， $\mathrm{F}_{\mathrm{k}}$ (変形) には複数の画像間で サブピクセル精度の正確な位置合わせが必要であり，この 位置合わせ技術として，例えば文献10）11）のような検討 例がある. $\mathrm{E}_{\mathrm{k}}$ (ノイズ) は，文献4)のようにガウシアンノ イズで代用されることが多い.しかし， $\mathrm{D}_{\mathrm{k}}$ (画像縮小)に ついては，倍率を既知とするのが一般的であり，入力画像 から推定する技術の検討例は見当たらない.

この $\mathrm{D}_{\mathrm{k}}$ (画像縮小)によって, 低解像画像 $\mathrm{Y}_{\mathrm{k}}$ に含まれる 折返し成分の周波数や位相が規定される．したがって， $\mathrm{D}_{\mathrm{k}}$ の設定が不正確だと, 式 (1)の逆演算の際に, 折返し成分 から高周波成分への復元が正しく行われない。

また，画像を拡大する際の中心を，例えば画像の左上の角 とするか, 画像の中央とするか，によって，図 1 (b-4) に示 した拡大後のサンプリングキャリヤ (周波数 $\omega_{\mathrm{s}}{ }^{\prime}, 2 \omega_{\mathrm{s}}{ }^{\prime} \cdot \cdots$ ) の位相が変化し，これに伴って折返し成分の位相も変化す る。この位相が正しい值からずれると，折返し成分から復 元した信号成分とベースバンド信号成分との間で干渉が生 じ，信号が減衰したり，本来まっすぐだった線がうねった りする，本稿では，拡大後のサンプリングキャリヤの位相 を決定づける值を「リサンプリング位相」と呼ぶことにし， 次章で詳しく述べる.

図2に，位相ずれの一例を示す，同図は，横方向に等間 隔で描いた 3 本の基準線の上に，この間隔を 1 周期 $\left(360^{\circ}\right)$ として正弦波状に縦方向の明暗が変化する模様を 3 本の横 線として描いたものである．同図に示すように，基準線上 からの位相を縦方向に $0^{\circ}$ から $20^{\circ}$ まで変化させると, 位相 ずれが約 $4^{\circ}$ 以下であれば本来の位相 $\left(0^{\circ}\right)$ との差がほとん ど判別できないが，位相ずれが約 $5^{\circ}$ を超えると差が判別で きるようになることがわかる.

このように，拡大 (逆演算では縮小) の倍率 (すなわち, 拡大前 (未知) と拡大後 (既知) の画素数の比) やリサンプリ ング位相を式 (1)に正しく設定することによって，高解像 画像を正しく復元できるようになる。したがって，拡大処 理の詳細が未知のアップコンバート画像を超解像処理する 


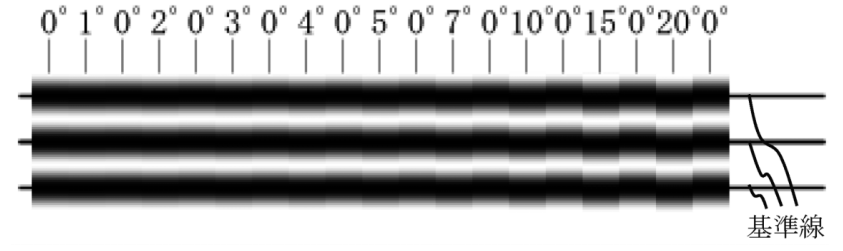

図2 位相ずれの一例

場合には，拡大前の画素数とリサンプリング位相を正しく 推定することが重要である.

\section{3. 提案する画素数・位相推定法}

筆者らは，後述するように，アップコンバート画像の信 号を複素平面上にプロットしたときに，拡大前のナイキス 卜周波数 (サンプリング周波数の $1 / 2$ の周波数) の成分の分 布が，他の周波数成分の分布と異なることに着目した。本 章では，この性質を利用し，1次元フーリエ変換と主成分 分析を用いることによって, アップコンバート画像におけ る拡大前の画素数およびリサンプリング位相を推定する手 法を提案する。

\section{1 リサンプリング位相}

本稿では, リサンプリング位相 $\theta_{\mathrm{RS}}$ を，図3に示すよう に「画像の端（左端あるいは上端）における拡大前のサンプ リングキャリヤの位相」と定義することにする．この位相 は, 拡大前後の各画素数と拡大中心の位置によって一意に 定まる，例えば，同図 (a)に示すように，画像の左端を基 準として拡大した場合のリサンプリング位相は 0 だが，同 図（b）に示すように画像の中央を基準として拡大した場合 は以下のようになる。

拡大前の画像の画素数を $\mathrm{k}$ とすると，画像の端から中央ま

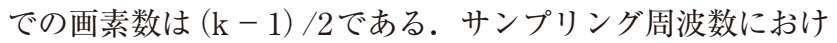
る画素間隔の位相差は $2 \pi$ なので，画像の中央では，端より も $2 \pi(\mathrm{k}-1) / 2(=\pi(\mathrm{k}-1))$ だけ位相が進むことになる. 一方，拡大後の画像の画素数を $\mathrm{k}$ とすると，画像の端から中 央までの画素数は $\left(\mathrm{k}^{\prime}-1\right) / 2$ である。また，拡大前のサン プリング周波数 $\omega_{\mathrm{s}}$ が，拡大後には $\omega_{\mathrm{s}} \cdot \mathrm{k} / \mathrm{k}$ に変換される. したがって, 拡大後の画素間隔では元のサンプリング周波 数成分の位相差は $2 \pi \mathrm{k} / \mathrm{k}^{\prime}$ となり, 画像の端では, 画像の中 央よりも $2 \pi\left(\mathrm{k}^{\prime}-1\right) / 2 \cdot \mathrm{k} / \mathrm{k}^{\prime}\left(=\pi\left(\mathrm{k}^{\prime}-1\right) \mathrm{k} / \mathrm{k}^{\prime}\right)$ だけ位相が 遅れることになる.画像の中央を基準として拡大した場合， 中央の位相は拡大の前後で変わらないので, 画像の端のリ サンプリング位相 $\theta_{\mathrm{RS}}$ は, 式 (2)のように表すことができる.

$$
\begin{aligned}
\theta_{\mathrm{RS}} & =\pi(\mathrm{k}-1)-\frac{\pi\left(\mathrm{k}^{\prime}-1\right) \mathrm{k}}{\mathrm{k}^{\prime}} \\
& =\frac{\pi\left(\mathrm{k}-\mathrm{k}^{\prime}\right)}{\mathrm{k}^{\prime}}
\end{aligned}
$$

3.2 画像の拡大前後における折返し成分の挙動

複雑な波形を持った信号も, 単純な正弦波の線形和で表 すことができる。そこで，信号 $\mathrm{s}(\mathrm{t})$ のうち周波数 $\omega$ を持っ

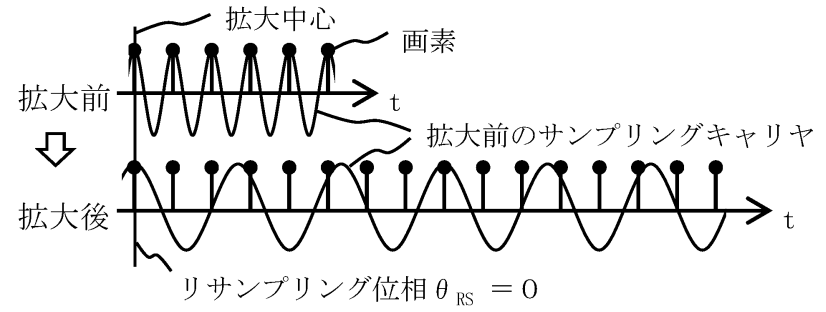

(a) 画像の端を拡大中心とした場合

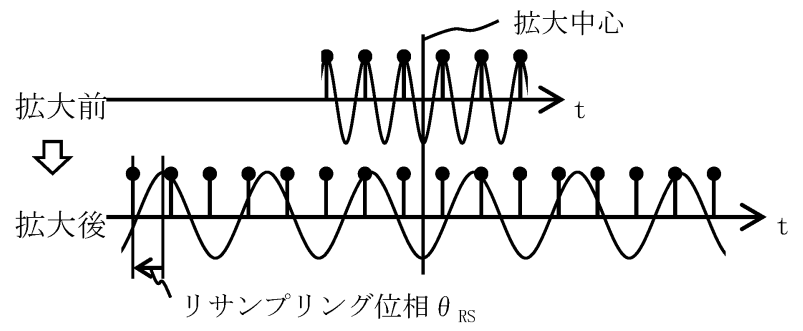

（b）画像の中央を拡大中心とした場合

図3リサンプリング位相（例：8/3倍拡大）

たベースバンド成分を，以下に示す正弦波とする.

$$
\begin{aligned}
s(t) & =A \cos (\omega t+\delta) \\
& =\frac{A\left(e^{j(\omega t+\hat{\partial})}+e^{-j(\omega t+\hat{\partial})}\right)}{2}
\end{aligned}
$$

なお，Aは信号振幅， $\delta$ は画像の内容に応じた任意の值 を持つ位相, $\mathrm{j}$ は虚数単位を表す。また, 式 (3) 第 1 項は, 複素平面上で左回りする正の周波数成分を表し，同第 2 項 は，複素平面上で右回りする負の周波数成分を表す.

ここで, 拡大前 (すなわち撮像時) のサンプリング周波数 を $\omega_{\mathrm{S}}$ とし，拡大後のサンプリング周波数を $\omega_{\mathrm{S}}$ （ただし， $\left.\omega_{\mathrm{S}}>\omega_{\mathrm{S}}\right)$ とする。簡単のため拡大を理想的な処理とする と, 図 1 (b-4)より $0 \leqq \omega \leqq \omega_{\mathrm{S}}{ }^{\prime} / 2$ の周波数範囲だけを考え ればよく, 拡大後の信号 $\mathrm{s}^{\prime}(\mathrm{t})$ はリサンプリング位相 $\theta$ RS を用いて (4) 式で表すことができる.

$$
\mathrm{s}^{\prime}(\mathrm{t})=\frac{A \mathrm{e}^{\mathrm{j}(\omega \mathrm{t}+\delta)}}{2}+\frac{\mathrm{Be}^{\mathrm{j}\left(\omega_{\mathrm{s}} \mathrm{t}+\theta_{\mathrm{RS}}-\omega \mathrm{t}-\delta\right)}}{2}
$$

なお, 式 (4) 右辺の第 2 項は撮像時の標本化により発生し た折返し成分，Bはこの成分の信号振幅である.

ここで筆者らは, 拡大前のナイキスト周波数 $\omega_{\mathrm{N}}\left(=\omega_{\mathrm{S}} / 2\right)$ では，周波数領域での対称性により，ベースバンド成分と折 返し成分の信号振幅は必ず一致することに着目した。この性 質を利用し， $\omega=\omega_{\mathrm{N}}$ における信号 $\left.\mathrm{s}^{\prime}(\mathrm{t})\right|_{\omega=\omega_{\mathrm{N}}}$ は，信号振幅 $\mathrm{B}=\mathrm{A}, \quad \omega_{\mathrm{S}}=2 \omega_{\mathrm{N}}$, および $\mathrm{e}^{\mathrm{j} \alpha}+\mathrm{e}^{\mathrm{j} \beta}=2 \mathrm{e}^{\mathrm{j}(\alpha+\beta) / 2} \cos ((\alpha-\beta) / 2)$ を 用いて，以下のように変形できる.

$$
\begin{aligned}
\left.\mathrm{s}^{\prime}(\mathrm{t})\right|_{\omega=\omega_{\mathrm{N}}} & =\frac{A \mathrm{e}^{\mathrm{j}\left(\omega_{\mathrm{N}} \mathrm{t}+\delta\right)}}{2}+\frac{A \mathrm{e}^{\mathrm{j}\left(\omega_{\mathrm{S}} \mathrm{t}+\theta_{\mathrm{RS}}-\omega_{\mathrm{N}} \mathrm{t}-\delta\right)}}{2} \\
& =A \mathrm{e}^{\frac{\mathrm{j}\left(\omega_{\mathrm{S}} \mathrm{t}+\theta_{\mathrm{RS}}\right)}{2}} \cos \left(\omega_{\mathrm{N}} \mathrm{t}+\delta-\frac{\omega_{\mathrm{S}} \mathrm{t}+\theta_{\mathrm{RS}}}{2}\right) \\
& =A \mathrm{e}^{\mathrm{j( \omega _{ \textrm {N } } \mathrm { t } + \frac { \theta _ { \mathrm { RS } } } { 2 } )} \cos \left(\delta-\frac{\theta_{\mathrm{RS}}}{2}\right)}
\end{aligned}
$$


式 (5)の右辺において，信号振幅 $\mathrm{A}$ と $\cos \left(\delta-\theta_{\mathrm{RS}} / 2\right)$ は 実数のため, 複素平面上における信号の回転には寄与せず, 虚数を含む $\mathrm{e}^{\mathrm{j}\left(\omega_{\mathrm{NL}}+\theta_{\mathrm{RS}} / 2\right)}$ のみによって回転する。この回転の 初期位相 $\left(\theta_{\mathrm{RS}} / 2\right)$ は, 入力信号の位相 $\delta$ には依存しない.

\section{3 提案する画素数・位相推定法の動作原理}

3.2節で述べた現象を利用した画素数・位相推定法の動作原 理を，図4に示す．まず，同図 (a) に画像信号の周波数スペク トルの一例を示す. 拡大前のナイキスト周波数 $\omega_{\mathrm{N}}$ を超えた原 信号の高周波成分は， $\omega_{\mathrm{N}}$ を対称軸として折返し成分に変換さ れている. ここで, 周波数 $\omega=\omega_{1}, \omega_{2}, \omega_{3}, \omega_{4}\left(=\omega_{\mathrm{N}}\right), \omega_{5}$ を例に挙げ, 各周波数における信号成分の実部と虚部を複 素平面上にプロットすることを考える.

折返し成分は，原信号に含まれる負の周波数成分がサン プリングキャリヤによって周波数シフトしたものであるこ とを考慮すると, 図4 (b) に示す複素平面上で, ベースバ ンド成分は左回りに，折返し成分は右回りに，それぞれの 信号振幅に応じた半径の円軌道上を回転していると考える ことができる。なお，同図中に示す位相は，式 (5)におけ る $\theta_{\mathrm{RS}} / 2$ である.

図 4 (a) に示した周波数 $\omega=\omega_{1}, \omega_{2}, \omega_{3}, \omega_{4}\left(=\omega_{\mathrm{N}}\right), \omega_{5}$ における信号成分の実部と虚部を複素平面上にプロットす ると, $\omega=\omega_{1}$ の周波数にはベースバンド成分しか存在せ ず, 離れた画素位置の信号強度や位相は一般に無相関であ るため, 同図 (c-1) に示すように, プロットした各点は円 状に散らばった分布になる。

$\omega=\omega_{2}$ の周波数では, $\omega=\omega_{1}$ のときと同様にベースバ ンド成分しか存在しないため, 図4 (c-2) に示すように, プ ロットした各点は円状に散らばった分布になるが, 円の半 径は信号振幅に応じて変化する.

$\omega=\omega_{3}$ の周波数では, 図 4 (a) に示すように折返し成分 をわずかに含んでいる．同図（b）に示すようにベースバン ド成分と折返し成分は互いに逆方向に回転をしているた め, 两者のベクトル和の分布は, 同図 (c-3) に示すように, 真円ではなく楕円状になる。

$\omega=\omega_{4}\left(=\omega_{\mathrm{N}}\right)$ の周波数では，折返しの対称軸上にあた るため, ベースバンド成分と折返し成分の信号強度は必ず 一致することに筆者らは着目した。この周波数では，互い に逆回転するベースバンド成分と折返し成分の各信号強度 が等しくなるため, 両者のベクトル和の分布は, 同図 (c-4) に示すような直線状になる，また，この直線と実軸のなす 角は，式 (5) より $\theta_{\mathrm{RS}} / 2$ となる.

$\omega=\omega_{5}$ の周波数では, 信号が減衰しているため, 複素 平面上にプロットした各点は, 同図 (c-5) に示すように原 点付近に集中し，ノイズによって円状の分布になる.

折返し成分が一旦発生してしまえば，途中で他の信号処 理が入っても, ベースバンド成分と折返し成分の信号強度 が一致する関係は保存される。したがって，アップコン バート画像の信号成分の実部と虚部を複素平面上にプロッ トしたときに，その分布が最も直線状になるときの周波数

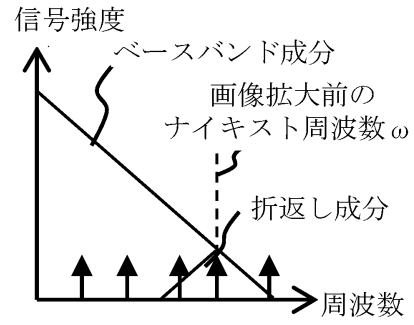

$\omega_{1} \quad \omega_{2} \quad \omega_{3} \omega_{4} \quad \omega_{5}$ (a) 周波数スペクトル

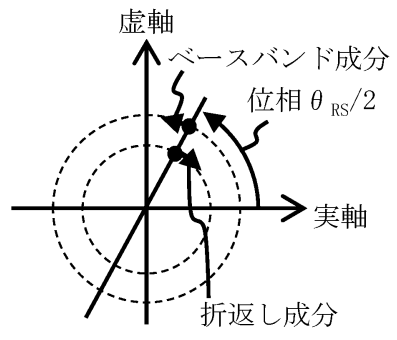

(b) 複素平面上の位相関係

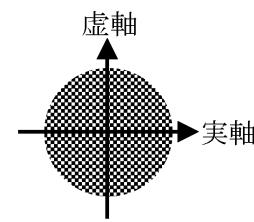

(c-1) 周波数 $\omega_{1}$

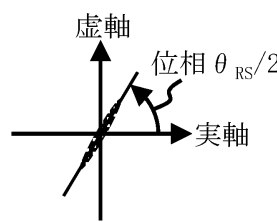

(c-4) 周波数 $\omega_{4}$

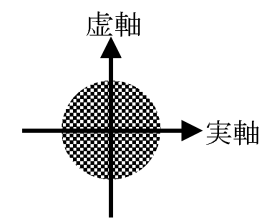

(c-2) 周波数 $\omega_{2}$

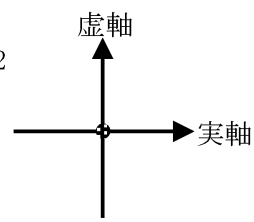

$(\mathrm{c}-5)$ 周波数 $\omega_{5}$

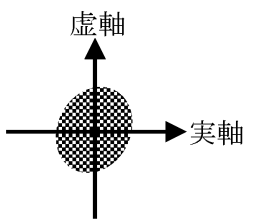

$(c-3)$ 周波数 $\omega_{3}$

画像拡大前の ナイキスト周波数では ベースバンド成分と 折返し成分の 信号強度が等しい 複素平面上の 信号成分の分布が 直線状になる
図4 提案する画素数・位相推定法の動作原理

が，画像拡大前のナイキスト周波数 $\omega_{\mathrm{N}}$ である，と推定で きる。

ここまで，1次元方向の拡大について議論してきたが，2 次元方向 (画像の水平方向と垂直方向)についても，それぞ れ独立した 1 次元方向として考えることができる.すなわ ち，前述した画素数 $\mathrm{k}$ を水平画素数 $\mathrm{w}$ あいは垂直画素数 $\mathrm{h}$ に，位置 $\mathrm{t}$ を水平位置 $\mathrm{x}$ あるいは垂直位置 $\mathrm{y}$ に，周波数 $\omega$ を水平周波数 $\mu$ あるいは垂直周波数 $v$ に, 位相 $\theta$ を水平位 相 $\phi$ あるいは垂直位相 $\psi$ にそれぞれ置換すれば，式 (2)や 式（5）をそのまま用いることができる.

なお，画像の水平周波数を，画面の横幅を基準とした lpw (lines per width)の単位で表すと, 水平方向のナイキ スト周波数を表す数值 (lpw) は, 画像の水平画素数と一致 する. 同様に, 垂直方向のナイキスト周波数を表す数值 (lph: lines per height) は, 画像の垂直画素数と一致する. したがって，水平方向および垂直方向の各ナイキスト周波 数を求めれば, その值が画像拡大前の水平および垂直の各 画素数を示すことになる.

\section{4 提案する画素数・位相推定法の構成}

3.3 節で述べた画素数・位相推定法の具体的な構成を図 5 に示す. 同図において, 拡大後の水平画素数が $\mathrm{w}$, 垂直画 素数がh’のアップコンバート画像をもとにして, 同図の上 半分の処理で，拡大前の水平ナイキスト周波数 $\mu_{\mathrm{N}}$ （すな わち, 水平画素数 $\mathrm{w})$ と水平リサンプリング位相 $\phi_{\mathrm{RS}}$ を求 め, 同図の下半分の処理で，拡大前の垂直ナイキスト周波 数 $v_{\mathrm{N}}$ (すなわち, 垂直画素数h）と垂直リサンプリング位 


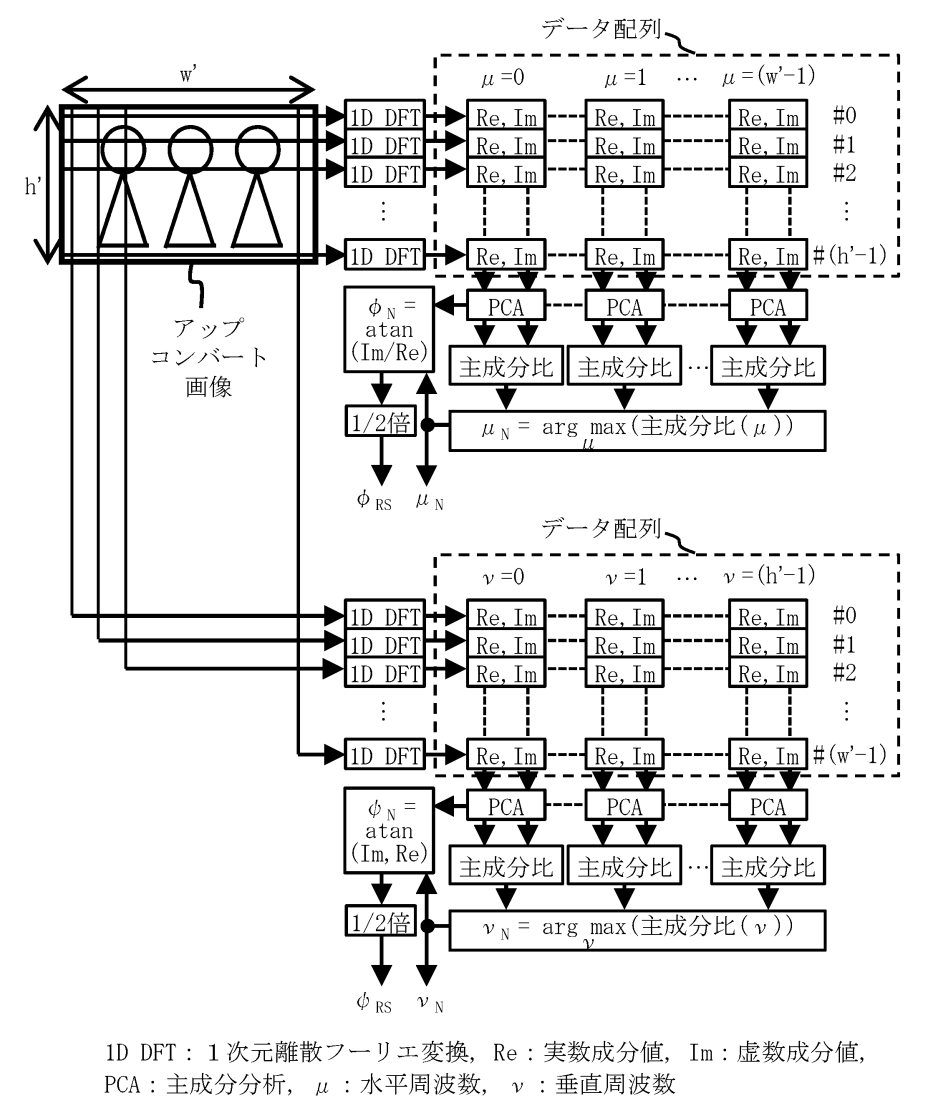

図5 提案する画素数・位相推定法の構成

相 $\psi_{\mathrm{RS}}$ を求める.

まず，図5の上半分の処理において，アップコンバート 画像の各画素值を, 水平方向に 1 行ずつ 1 次元離散フーリ 工変換 (1D DFT: One Dimensional Discrete Fourier Transform) し, 水平周波数 $\mu=0$ から $\mu=\left(\mathrm{w}^{\prime}-1\right)$ (単位： lpw) までの実数成分值 (Re) と虚数成分值 (Im) を求める. 続いて, 同一の周波数成分におけるすべての行の実数成分 值 $(\mathrm{Re})$ と虚数成分值 $(\mathrm{Im})$ の組をまとめて 2 次元データと し, 周波数ごとに図 4 (c) に示すような複素平面上の分布 を得る。

ここで，この分布が直線状かどうかを判定するために， 2 次元データ (Re, Im) の主成分分析 (PCA: Principal Component Analysis) を行い, PCAの結果における第1主 成分の固有值 $\left(\lambda_{1}\right)$ と第 2 主成分の固有值 $\left(\lambda_{2}\right)$ を比較して, $\lambda_{1} \gg \lambda_{2}$ となっていれば直線状である, と判定することに した．このとき， $\lambda_{2}$ の值が小さいほど直線状の分布にな るため, $\lambda_{1}$ と $\lambda_{2}$ の比 $\left(\lambda_{1} / \lambda_{2}\right)$ を「主成分比」と定義し, この主成分比が最も大きくなったときに直線状の分布に なったと判定して, そのときの水平周波数 $\mu$ を「拡大前の 水平ナイキスト周波数 $\left.\mu_{\mathrm{N}}\right\rfloor$ (すなわち, 拡大前の水平画素 数w) と推定する.

また，主成分比 $\left(\lambda_{1} / \lambda_{2}\right)$ が最も大きくなったときの第 1 主成分の固有べクトルの方向 $(\mathrm{Re}, \mathrm{Im})$ から位相 $\theta_{\mathrm{RS}} / 2$ (=atan $(\mathrm{Im} / \mathrm{Re}))$ を求め, この值を 2 倍することによって, 水平リサンプリング位相 $\theta_{\mathrm{RS}}$ を推定する.
同様に，図5の下半分の処理において，アップコンバート 画像の各画素值を, 垂直方向に1列ずつ 1 次元離散フーリエ 変換 $(1 \mathrm{D}$ DFT) し，その後は同図の上半分と同一の処理を 行うことによって, 拡大前の垂直ナイキスト周波数 $v_{\mathrm{N}}$ (す なわち, 拡大前の垂直画素数h) と垂直リサンプリング位相 $\psi_{\mathrm{RS}}$ を推定することができる。

\section{4.シミュレーション実験}

3 章で述べた提案手法の有効性を確認するために, 以下 に述べる実験を行った。実験には，図6に示すITE標準動 画像 $(720 \times 480$ 画素，プログレッシブ走査）を用いた.

まず，図6 (a) に示す画像 (1フレーム) を原画とし，一般 的なバイキュービック補間により，画像の中央を拡大中心 として，水平方向に $8 / 3$ 倍，垂直方向に $9 / 4$ 倍に拡大した アップコンバート画像 $(1920 \times 1080$ 画素)を作成した。こ の画像に対して図 5 に示した処理を行い，3章で述べた周 波数ごとの主成分比を求めて，水平および垂直の拡大前の 画素数とリサンプリング位相を推定した.

図7 (a-1)（a-2）に，水平と垂直の各主成分比を示す。同 図の横軸は水平周波数あるいは垂直周波数を示し, 縦軸は 各周波数に対応した主成分比 $\left(\lambda_{1} / \lambda_{2}\right)$ を示す。なお, 縦 軸の主成分比については, 見やすいように, 全周波数の中 で最も大きな主成分比が一定值 (1.0) となるように線形正 規化して示している．同図(a-1)（a-2）において，拡大前の

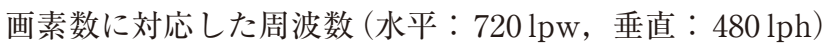




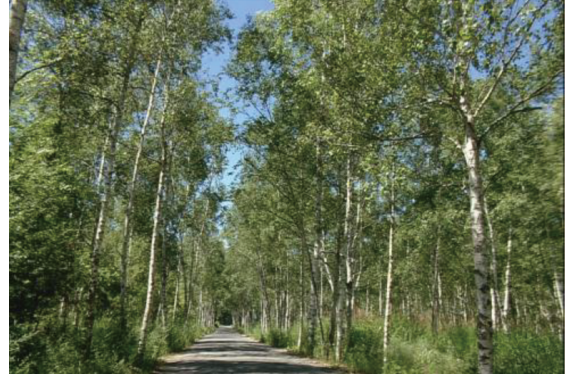

(a)「Green Leaves」(300フレーム目)

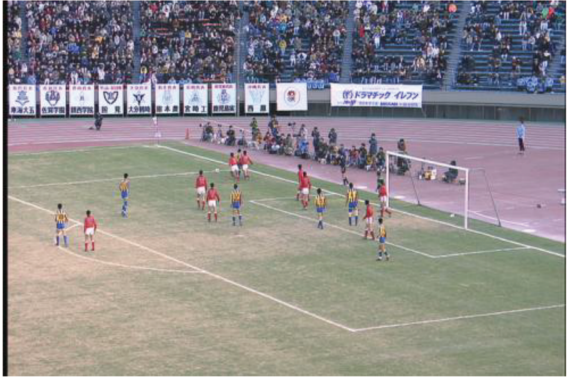

(b)「Soccer Action」(300フレーム目) 図6 実験に使用した画像

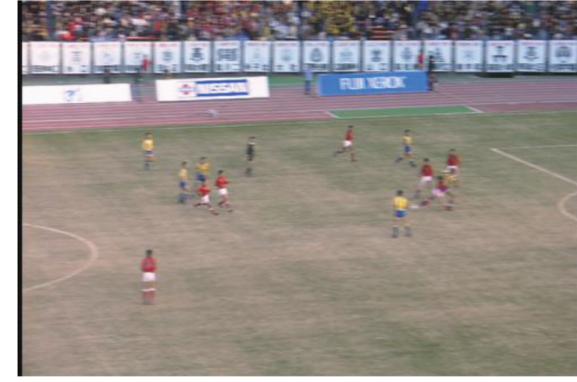

(c)「Soccer Action」(900フレーム目)

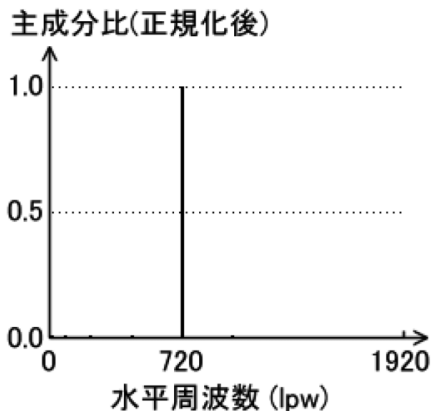

$(a-1)$ 水平主成分比

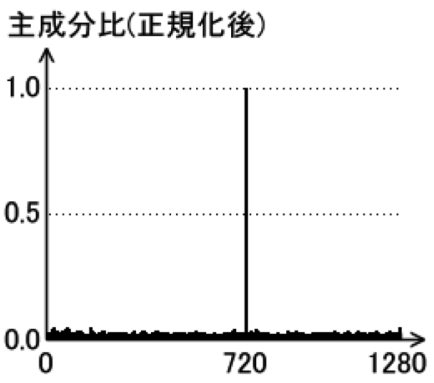

水平周波数 (lpw)

$(b-1)$ 水平主成分比

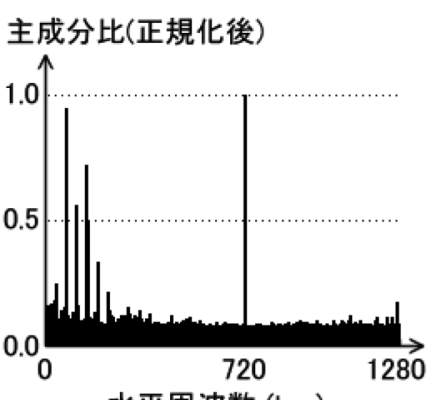

水平周波数 (lpw)

$(c-1)$ 水平主成分比

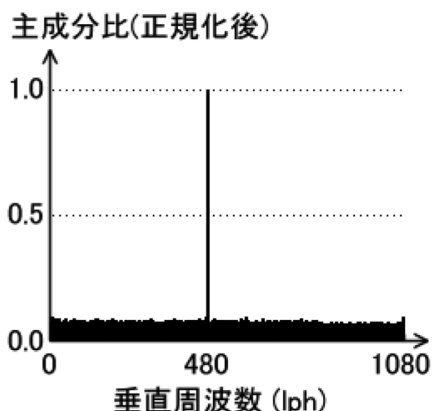

(a-2) 垂直主成分比

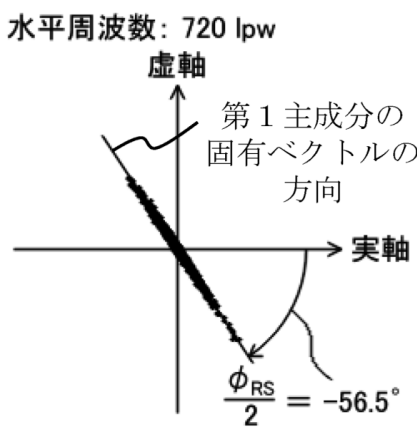

$(a-3)$ 水平成分分布

(a)「Green Leaves」(300フレーム目)

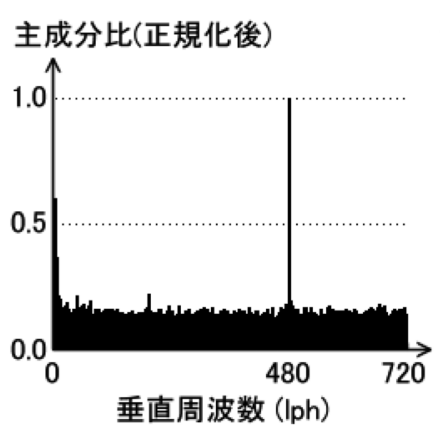

(b-2) 垂直主成分比

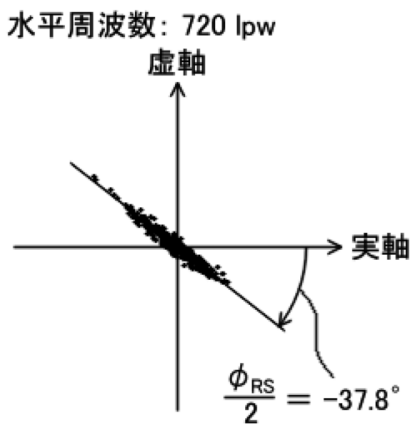

$(b-3)$ 水平成分分布

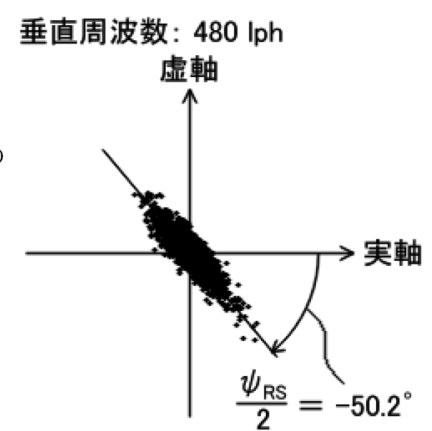

(a-4) 垂直成分分布

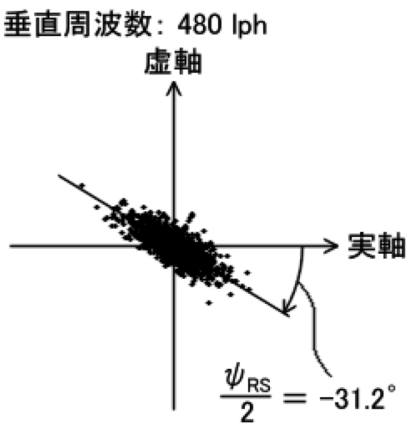

(b-4) 垂直成分分布

(b)「Soccer Action」(300フレーム目)

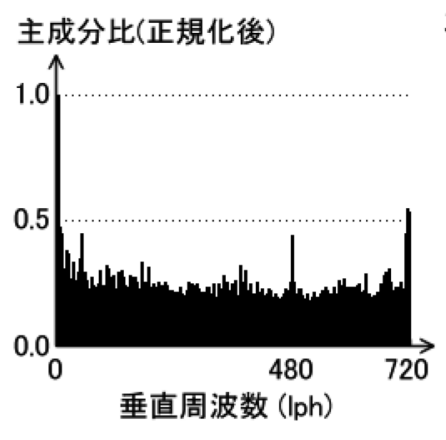

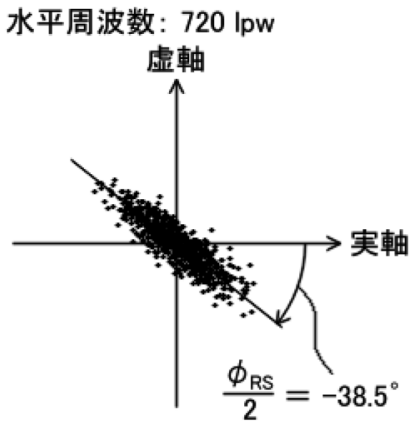

$(\mathrm{c}-3)$ 水平成分分布

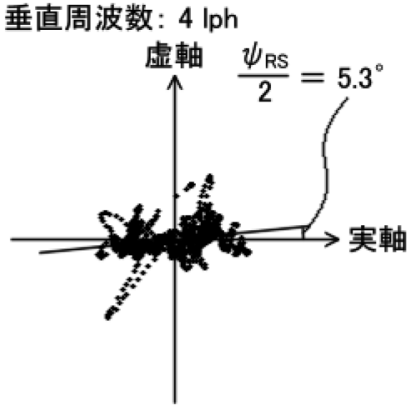

(c-4) 垂直成分分布

(c)「Soccer Action」(900フレーム目)

図7 提案する画素数・位相推定法の実験結果

の主成分比が突出して大きくなっており, 拡大前の画素数 を正しく推定できていることがわかる.

図 7 (a-3)（a-4）に，拡大前の水平と垂直の各ナイキスト
周波数における複素平面上の信号の分布を示す。それぞれ の第 1 主成分の固有べクトルと実軸がなす角が，各リサン プリング位相の $1 / 2$ を示しているはずである. 
式 (2) を用いて, 拡大前後の画素数から各リサンプリング 位相を求めると, 以下のようになる. まず, 水平については, $\mathrm{k}=\mathrm{w}=720, \mathrm{k}^{\prime}=\mathrm{w}^{\prime}=1920$ とおくと, $\theta_{\mathrm{RS}}=\phi_{\mathrm{RS}}=\pi\left(\mathrm{k}-\mathrm{k}^{\prime}\right)$ $/ \mathrm{k}^{\prime}=\pi(720-1920) / 1920=-5 \pi / 8=-112.5^{\circ}$ となり, 眓 7 (a-3) に示した $\phi_{\mathrm{RS}} / 2=-56.5^{\circ}\left(\phi_{\mathrm{RS}}=-113^{\circ}\right)$ とよく一致し ている. 同様に, 垂直についても, $\theta_{\mathrm{RS}}=\psi_{\mathrm{RS}}=\pi(480-$ 1080) $/ 1080=-5 \pi / 9 \pi=-100^{\circ}$ となり, 図7 (a-4)に示した $\psi_{\mathrm{RS}} / 2=-50.2^{\circ}\left(\psi_{\mathrm{RS}}=-100.4^{\circ}\right)$ とよく一致し, リサンプ リング位相をほぼ正しく推定できていることがわかる.

続いて, 図6 (b) および (c) に示す画像を原画とし, 先ほ どとは拡大の条件を変更して, 一般的なバイリニア補間に より，画像の中央を拡大中心として，水平方向に16/9倍， 垂直方向に $3 / 2$ 倍に拡大したアップコンバート画像 $(1280 \times 720$ 画素 $)$ を作成して, 同様の実験を行った。ここ で, 同図 (b) (c) は一連の動画から抜粋したフレームであ るが，（c）は（b）に比べてカメラが大きく水平移動 (パン) しており大幅な解像度低下 (ぼけ) が生じている.

図7 (b-1)（b-2）に示すように, 水平・垂直ともに主成分 比が突出して大きくなる周波数が存在し, 各ナイキスト周 波数を正しく推定できている，また，リサンプリング位相 については, 同図 (b-3) (b-4) に示す各值 $\left(\phi_{\mathrm{RS}} / 2=-37.8^{\circ}\right.$ $\left(\phi_{\mathrm{RS}}=-75.6^{\circ}\right)$, および $\left.\psi_{\mathrm{RS}} / 2=-31.2^{\circ}\left(\psi_{\mathrm{RS}}=-62.4^{\circ}\right)\right)$ となった. 式 (2) から求めた理論值 $\left(\phi_{\mathrm{RS}}=\pi(720-1280)\right.$ $\left./ 1280=-78.75^{\circ}, \psi_{\mathrm{RS}}=\pi(480-720) / 720=-60^{\circ}\right)$ と比

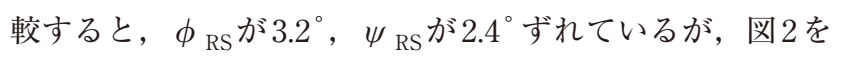
参照すると, この程度の位相ずれは実運用上問題にならな いと考えられる.

その一方で, 図7 (c-1) (c-2)については, 拡大前のナイキ ス卜周波数以外にも大きな主成分比が見られる. 特に, 垂 直については, 同図 (c-2) に示すように, $0 \mathrm{lph}$ と $720 \mathrm{lph}$ の近 傍にそれぞれ大きな主成分比がある。その結果，同図 (c-4) に示すように, 拡大前の垂直ナイキスト周波数を $4 \mathrm{lph}$ と誤 推定してしまっている.

この誤推定は, 前述したカメラの大きな移動に伴う解像 度低下により, ナイキスト周波数成分が大きく減衰し, 複 素平面上にプロットした各点が原点付近に集まってしま い,ノイズによって明確な直線状の分布にならず, 他の周 波数の主成分比が相対的に大きくなってしまったことが原 因と考えられる。

本提案手法の原理上, 前述のように拡大前のナイキスト 周波数成分が大きく減衰している場合には, 拡大前の画素 数とリサンプリング位相を正しく推定することができな い. しかし, この場合には, 折返し成分を利用した超解像 処理ではもともと大きな効果は期待できないと考えられ る. したがって, 主成分比が大きくなる周波数が複数検出 されて拡大前の画素数を推定できないときには, 超解像処 理を止めるなどの対策を講じることにより，実運用上は問 題にならないと考えられる.

\section{5. むすび}

未知の倍率で拡大されたアップコンバート画像における 「拡大前の画素数および折返し成分の位相を決定づけるリ サンプリング位相」を推定する手法を提案し, シミュレー ション実験によってその有効性を示した。

本手法において，拡大前のナイキスト周波数では，ベー スバンド成分と折返し成分の信号強度が必ず一致し，アッ プコンバート画像信号の実部と虚部を複素平面上にプロッ トすると，直線状に分布することを利用する.

なお，本手法の原理上，拡大前のナイキスト周波数成分 が減衰している場合や折返し成分がない場合には，拡大前 の画素数とリサンプリング位相を正しく推定することがで きない。また，テストチャート（例えば，円形ゾーンプ レートなど)のように, 離れた画素位置の信号強度や位相 が無相関でない場合や，1枚の画像の中にさまざまな倍率 で拡大された複数の画像が混在して貼り込まれている場合 にも本手法は適用できないため，これらの対策が今後の課 題である.

\section{〔文 献〕}

1）田中, 奥富：“画素数の壁を打ち破る 複数画像からの超解像技術”, 映情学誌，62，3, pp.337-342（2008）

2) R. Schultz and R. Stevenson: "A Bayesian Approach to Image Expansion for Improved Definition", IEEE Trans. Image Processing, 3, 3, pp.233-242 (1994)

3) M. Irani and S. Peleg: "Improving Resolution by Image Registration", CVGIP, 53, 3, pp.231-239 (1991)

4) S. Farsiu et al: "Fast and Robust Multiframe Super Resolution", IEEE Trans. On Image Proc., 13, 10, pp.1327-1344 (2004)

5) R. Tsai and T. Huang: "Multiframe Image Restoration and Registration", Advances in Computer Vision and Image Processing. 1, 2, pp.317-339 (1984)

6）上田，大森：“位相シフト画像を用いた画像の高精細化”，1994年テ レビ年次大， 8-1, pp.111-112（1994）

7）影山, 浜田：“画像の位相シフトを利用した超解像再構成処理の適用 可能性と 2 次元拡張に関する検討”, 映情学誌，68，6, pp.J247-J251 (2014)

8) W. Richardson: "Bayesian-based iterative method of image restoration", J. Opt. Soc. Am., 62, 1, pp.55-59 (1972)

9）浅井ほか：“ケプストラム解析を用いたブレ画像のBlind Deconvolution", 2009-CVIM-167，26，1-8 (2009)

10) R. Szeliski and D. Scharstein: "Symmetric sub-pixel stereo matching", Proc. European Conf. Computer Vision, 2, pp.525-540（2002）

11)B. Zitova and J. Flusser: "Image registration methods : A survey", Image Vis. Comput., 32, 11, pp.977-1000 (2003)

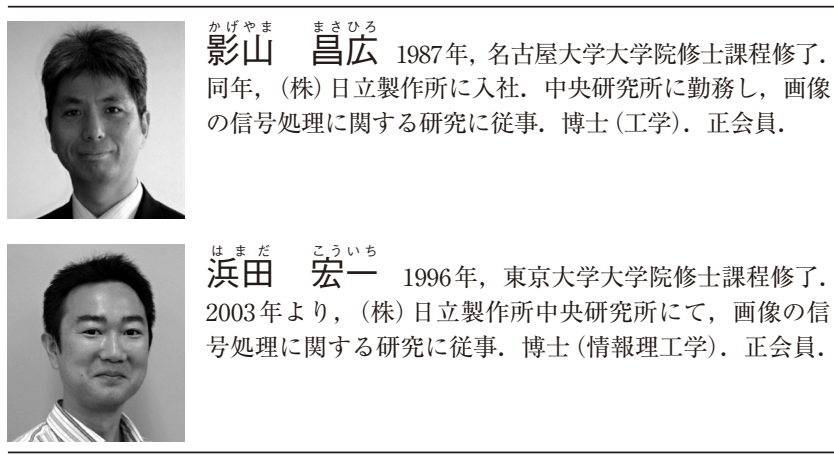

